\title{
MANAGEMENT EFFICIENCY
}

\author{
Marek PAWŁOWSKI*, Zdzisław PIĄTKOWSKI**, Wojciech ŻEBROWSKI*** \\ *Higher School of Management in Warsaw, 03-772 Warszawa, Poland \\ drmarekpawlowski@wp.pl \\ **University of Ecology and Management in Warsaw, 02-061 Warszawa, Poland \\ ***Faculty of Management, Department of Production Management \\ Warsaw University of Technology, 02-524 Warszawa, Poland \\ W.Zebrowski@wz.pw.edu.pl
}

\begin{abstract}
Modern management process may be viewed as one constant series of decision making and creation of conditions for effective decision realization. In the process of organizing it is important to verify the organization effectiveness and implement corrections in order to maintain or increase this effectiveness. For the purpose of situation diagnosis and improvement of organization's results, the three-efficiency-levels approach is used (organization level, process level, workstation level). Degree of decision effectiveness (efficiency) will depend on rationality of the problem solving process. Therefore, it is necessary to determine the primary and supporting goals as well as strategies for their realization and to take care of the quality of organization's internal activities, which includes full readiness for cooperation and flexibility towards changes.
\end{abstract}

Key words: Modern management, production management system, organization effectiveness, management efficiency, economic efficiency, managerial work improving methods, performance, productivity.

\section{Introduction}

This article is a continuation of its authors' considerations included in two previous articles $[23,34]$ related to company logistics and production management.

In the first of those articles, when describing chosen aspects of system concept of logistics from the efficiency point of view, the authors mentioned a method of affecting efficiency in a logistics system and presented five different relation variants (initial outlay, results) referring to the shape the efficiency formula takes.

Also the authors mentioned shaping of logistics system efficiency from the view of assumptions and phases of logistics development [23].

In the second article, on the other hand, the modern production management systems were compared with regard to utilitarian efficiency [34].

Visibly, the efficiency issue was signalized in both mentioned articles, and its broader description will be the subject of this article. As it is hard to propose a single logical construct of management efficiency (effectiveness, productivity) to the reader, the broad issue was narrowed down by the authors to some key areas.

\section{Research problems}

In the presented paper, the authors concentrate on a few important directions of management efficiency research, including:

- different approach to the essence of efficiency (effectiveness), way of its presentation and measurement,

- division of efficiency into: economic, organizational and managerial ones,

- essence of increasing of organization efficiency;

- determining the efficiency in processes of: planning, decision-making, organizing, coordinating, motivating and controlling,

- efficiency problems concerning human resources management process, especially with regard to: recruitment, selection, training and efficiency management system,

- gathering knowledge on the efficiency of management style and time management,

- methods of improving managerial work and increasing organization efficiency.

Plan of resolving the above mentioned issues will be based on identification of four key problems. 
First problem concerns defining efficiency as a unit of measurement of productivity: if we compare two mines with similar manpower, extracting the same type of coal in the same environmental conditions, with use of similar type of equipment, then the mine which extracts more coal is viewed to be more efficient.

Second problem concerns so called managerial efficiency, which refers to effectiveness of management as opposed to the effectiveness of the whole production unit.

Third problem is the degree to which a given firm should achieve the highest results in a particular, specific environment that surrounds it.

Fourth problem is the way of efficiency evaluation in the sense of the rate of profit. While from the point of view of an entrepreneur the highest capital efficiency is achieved when the rate of profit is maximized, from the society's point of view the most effective allocation of resources may be achieved i.e. when the rate of profit is minimal.

In works devoted to issues such as organization or management, the term efficiency is used in the same meaning as effectiveness or performance. P. F. Drucker used to say efficiency means kind of a habit. It is a matter of certain set of activities, which can always be trained. Later on, they will become a habit, which we learn by practicing and once again practicing. This is how competences are formed.

Efficiency, according to P. F. Drucker, is the key element of human and organizational development. It leads to self-fulfillment and allows a modern society to survive; it is the degree of target fulfillment [6, p. 182].

Efficiency is also, according to this author, the degree of realization of a goal. An extremely important problem in the activity of every entity with regard to this matter is, therefore, proper definition of goal as well as means for its realization.

Obtaining a positive result of actions should be accompanied by: precise identification and determination of the need for introduction of changes; planning and carrying out of a project, which serves the purpose of fulfillment of a certain need; involvement of the whole staff, who should be aware that effects of activity are massively determined by work quality, which, therefore, should be constantly improved, in order to result in an increase of resources management efficiency (including increase of profitability); maintaining pace and direction of changes, which is to help to fulfill a given need; constant improvement of actions in accordance with the Deming circle [28, p. 211].

\section{Basic concepts}

Organizational efficiency is not an unambiguous term. The literature presents various approaches to the essence of efficiency, way of its implementation and measurement. Also, many similar terms are used, such as: effectiveness, performance, productivity, economy [3, p. 103].

On the basis of professional literature from the scope of economics, economics of work, organization and management or social psychology, it can be stated that in the last 120 years there was a slow but systematic evolution of content and denotation of the term efficiency going on: "from a narrow technical and economic to a humanistic and ecological one" [7, p. 149].

Problem of efficiency has been discussed in Polish literature from the field of organization and directing with various regularity for the last 40 or so years. [31, p. 14$15]$.

The works concerning problems of organization and management use the term efficiency in the same meaning as effectiveness or performance.

Efficiency is the key element for human and organizational development. It leads to self-fulfillment and allows a modern society to survive; it is the degree of target fulfillment [5, p. 182].

Problem of efficiency cannot be looked at without referring to means and possibilities of its measurement. Issue of measuring efficiency is extremely important, while only then can any area or a whole company be managed, when the phenomena and processes can be measured and analyzed, with the use of even such concepts as time or costs. When speaking of efficiency, it is necessary to consider way of its evaluation. Efficiency is often measured by profitability, and the most effective allocation of resources is always made with micro and macro-scale interests in mind [28, p. 194].

Important problem in processes of efficiency measurement is the proper choice of methods. In this area, i.e. discount methods can be used, which allow evaluation of efficiency of developmental projects [5].

From the point of view of cybernetics, the scope of ex post activity efficiency concept refers to a certain relation between the obtained effects and the initial outlay needed for their realization. Ex ante activity efficiency, 
on the other hand, refers to the relation between the target and the anticipated means for its realization [5, p. 151].

Recently, two main approaches to efficiency, goaloriented one and system one, are underlined. The goaloriented approach assumes that organizations are established in order to achieve the undertaken goals. The system approach, on the other hand, that rarely are there all the resources in the surrounding. The meaning of purposefulness as a characteristic of an organization, which is a natural system resembling living organism, is underlined. Both these approaches, according to A. Kister, differ profoundly starting from basic assumptions, through the view on the essence of evaluation efficiency and stage-character, evaluation criteria, ending with efficiency measurement [12, p. 4].

"In general, productivity informs us how many units of product can be obtained from a unit of a certain factor" [29, p. 285].

R. Koch, on the contrary, says productivity is "every measure of production output divided by a measure of initial outlay (i.e. profit per unit of initial capital)". Apart from that, productivity is never an unambiguous goal in itself: by its evaluation one must consider the adopted measure and the motives which determined its choice. Often, a very good measure of productivity in many situations is the economic value added [14, p. 199].

Literature on the subject distinguishes between partial and total productivity. Partial productivity is the relation between total number of products (or number of products of certain type) and the amount of particular types of resources used for their manufacturing. Thus, this productivity refers to different production factors. Therefore, one can speak of: work productivity, capital productivity, land productivity, energy and resources productivity. Total productivity is the relation between the total number of products and total amount of resources used for their manufacturing [24. p. 341].

A Bobak, however, distinguishes between standard and structural productivity. Standard productivity (turnover) is the relation between total sales revenues and cost (value) of the production factor (resource) used. It allows comparing the revenue index in time that is the amount of revenues which falls on a monetary unit ploughed into project from the company resources. This type of productivity is distinguished by activity of production factors, as it is used in the economic processes.
Standard productivity is biased by the error of inadequacy, while only one factor determines the end effect. Standard productivity which produces effects through specific types of company activity aims at eliminating this problem. A necessary condition for its calculation is finding the part the particular types of activity have in the total company revenues, that is the end effect. Structural productivity is the relation of divided end effect (falling on a given activity) and costs of this type of activity. Statistical key figures used in this case serve the purpose of dividing the end effect into particular types of activity [4].

As stated by A. Kosieradzka [17], observation, evaluation and analysis of productivity in a company is a tool of successful management, and it enables:

- evaluation of results achieved by the company in comparison to other companies within the same industry,

- identification of 'weaknesses', that is these fields of operation which are the reason for poor productivity and which require improvement,

- establishing programs of productivity improvement;

- establishing strategic plans of a company,

- observation of trends of changes of partial and total productivity indices,

- linking company payroll policy with its productivity.

Market requirements force companies to constantly improve productivity and search for new ways of increasing it. In many countries, Japan in particular, increasing productivity is treated as a sort of company philosophy and forms a special movement towards productivity [24, p. 34].

\section{Economic efficiency}

Efficiency reveals itself in each purposeful human activity. However, when speaking of company results' analysis, it is necessary to: identify the effects, measure them, find a proper basis for comparison and formulate methods for synthetic evaluation of effects [2, p. 191].

Economic efficiency may be viewed as "a result of economic activity, defined by the relation between the effect and the initial outlay" [Polish Language Dictionary, PWN, Warsaw 2004]. An important feature of economic efficiency is the purposefulness of action. The scope of meaning of economic efficiency changes in time and, therefore, one can speak of a defined rela- 
tion between the achieved results and initial outlay as well as relation between activity goal and the means necessary for its achievement.

Economic efficiency is an important tool of management efficiency measurement, and is viewed as a certain boarder-line for achieving best results [2, p. 191].

Economic efficiency is related to productivity. At the same time, it is important to bear in mind a famous statement by M. Imai (president of Kaizen Institute): "even the biggest fool is able to increase his work efficiency, if he spends the proper amount of resources for this purpose. The true achievement is to increase efficiency without investing in new equipment" [2, p. 191].

In his actions, a manager has to use a broad spectrum of economic indices, which make the resource management easier. Manager concentrates his attention on the parameters of capital profitability and those referring to the ability to pay bills $[19$, p. 139].

Usually, "partners of a company are mainly interested in its liquidity ratios. This refers to banks which grant short-term loans and to suppliers who grant commercial credits. What is important for them are the current assets to current liabilities liquidity ratio. Current liabilities cannot exceed the level of current assets" [19, p. 139].

In a broader sense, the term economic efficiency refers to "the best results in production or distribution of products and services under the lowest costs. Efficiency is measured with the use of synthetic, partial indices of resource management productivity. Those indices, however, do not express precisely the efficiency of particular production factors, or the efficiency of a company as a whole.

The effects of economic activity are very complex: indirect and direct, positive and negative, desirable and undesirable. Many types of effects may be distinguished, i.e.: increase in work efficiency, increase of foreign exchange due to export of new production, increased profits, increased production volume, increased production quality as well as deterioration of working conditions, deterioration of environment..." [24, p. 100].

On the other hand, the efficiency of a company may be measured with the use of such variables as:

- productivity, that is output-input ratio,

- morale, that is the level of satisfaction of employees' material and emotional as well as higher needs, as a result of attaching more sense and meaning to goals and tasks,

- adaptation, that is company care about client satisfaction, high quality of products and services,

- flexibility, that is the degree of company adaptability to changes,

- institutionalization, that is the degree of society support for company's mission, goals, norms and values,

- stability that is low level of disturbance, good relationships between employees, managers and clients of the company [7, p. 193].

If the problems of economic efficiency evaluation are referred to production activity of organization, then it should be assumed that this efficiency will be determined by three factors:

- initial outlay incurred for the preparation of means for activity,

- effects in the form of new means (products),

- time of realization of specific action, in which the systems are used and the effects are generated.

\section{Organizational Efficiency}

Organizational efficiency is the ability of a company to currently and strategically adapt to changes in the environment, as well as productively and economically use its resources in order to realize the adopted structure of goals [7, p. 100].

It can be achieved when it is treated as a process for development. The true nature of efficiency is, therefore, a process, interactional process, which encompasses phenomena taking place inside of organization, as well as between the organization and its surrounding.

In the theory of organization management, the term efficiency is often replaced with the term performance. It is believed that the organization performs better, the bigger the degree to which it realizes its goals and the smaller the time and resources outlays for their realization [24, p. 100].

Organizational Efficiency is ensured by such factors as: product, plant, processes, programs and personnel. $[18$, p. 153, 158]. Those factors influence competitive advantage through: product - clear functions and unique operational characteristics; personnel - skills, training; plant - specific functions, operations, technologies; programs - quickness, preciseness, delivery 
punctuality, supply; processes - specific methods of work organization [2, p. 195].

Effectiveness - is the measure of the degree of goal realization. Result, that is the goal, is the anticipated state of nature, which we want to approach through our actions. We can either fully approach the goal (the result), approach it partially or not approach it at all (stand still), or even get farther from our goal. Our actions can, therefore, be:

- fully,

- partially,
- not at all (neutral),

- counter-effective (negative) [13, p. 22-24].

Natural striving of every thinking human being is to achieve maximum effectiveness of his actions. All normal people aim at achieving full and complete effectiveness of action. However, not everybody give a lot consideration to the conditions of goal realization, being under the illusion that the success will come by itself [13, p. 23].

Table 1. Company efficiency ratios (source: [19, p. 140-141])

\begin{tabular}{|c|c|c|c|}
\hline \multicolumn{4}{|c|}{ RATIOS } \\
\hline I. Operating efficiency: & II. Liquidity & III. Profitability: & IV. Market ratios \\
\hline $\begin{array}{l}\text { Return on sales = } \\
\text { Net Income } \\
\text { / Sales }\end{array}$ & $\begin{array}{l}\text { Debt ratio }= \\
\text { Total Debts } \\
/ \text { Total Assets }\end{array}$ & $\begin{array}{l}\text { Fixed Capital Structure } \\
\text { Ratio }= \\
\text { Equity } \\
\text { / Long-Term Liablilities }\end{array}$ & $\begin{array}{l}\text { Nominal Value } \\
\text { of Ordinary Share = } \\
\text { Share Capital } \\
\text { / Number of Ordinary } \\
\text { Shares }\end{array}$ \\
\hline $\begin{array}{l}\text { Profit margin }= \\
\text { Net Income } \\
\text { / Capital Employed }\end{array}$ & $\begin{array}{l}\text { Equity to Fixed Assets } \\
\text { Ratio = } \\
\text { Ownership Equity } \\
\text { / Fixed Assets }\end{array}$ & $\begin{array}{l}\text { Return on Capital }= \\
\text { Net Income + Financial } \\
\text { Costs } \\
\text { / Fixed Capital }\end{array}$ & $\begin{array}{l}\text { Earnings per share }= \\
\text { Income minus tax minus } \\
\text { preferred stock } \\
\text { / Number of Ordinary } \\
\text { Shares }\end{array}$ \\
\hline $\begin{array}{l}\text { Payback Period }= \\
\text { Capital Employed } \\
\text { / Net Income }\end{array}$ & $\begin{array}{l}\text { Fixed Assets Ratio = } \\
\text { Fixed Assets } \\
/ \text { Total Assets }\end{array}$ & $\begin{array}{l}\text { Financial Costs Ratio = } \\
\text { Financial Costs } \\
\text { / Average Long-Term } \\
\text { Liabilities and Credits } \\
\text { minus Free Cash }\end{array}$ & $\begin{array}{l}\text { Dividend per Ordinary } \\
\text { Share }= \\
\text { Dividends Paid } \\
\text { / Number of Ordinary } \\
\text { Shares }\end{array}$ \\
\hline $\begin{array}{l}\text { Turnover of Capital Em- } \\
\text { ployed = } \\
\text { Sales } \\
\text { / Capital Employed }\end{array}$ & $\begin{array}{l}\text { Current Assets Self- } \\
\text { Financing Ratio = } \\
\text { Current Liabilities } \\
\text { / Current Assets }\end{array}$ & $\begin{array}{l}\text { Return on equity }= \\
\text { Net Income } \\
\text { / Average Total Equity }\end{array}$ & $\begin{array}{l}\text { Dividend ratio }= \\
\text { Dividend per Share } \\
\text { / Share Market Value }\end{array}$ \\
\hline \multirow[t]{3}{*}{$\begin{array}{l}\text { Fixed Capital Investment } \\
\text { Ratio = } \\
\text { Fixed Capital Investment } \\
\text { / Amortization }\end{array}$} & $\begin{array}{l}\text { Current Ratio }= \\
\text { Current Assets } \\
/ \text { Current Liabilities }\end{array}$ & & $\begin{array}{l}\text { Return on Share }= \\
\text { Eernings Per Share } \\
\text { / Share Market Price }\end{array}$ \\
\hline & $\begin{array}{l}\text { Assets Liquidity Ratio }= \\
\text { Current Assets } \\
\text { / Total Assets }\end{array}$ & & \\
\hline & $\begin{array}{l}\text { Net Assets }= \\
\text { Current Assets minus } \\
\text { Current Liabilities }\end{array}$ & & \\
\hline
\end{tabular}


An effective organization is characterized by the following skills: it successfully wins resources, manages them appropriately, achieves the marked-out goals and fulfills the needs of its employees [2, p. 215].

Managerial effectiveness is one of the basic requirements in the game of organizational effectiveness and is the most important input in the organization development. Effectiveness is the hope for economic productivity and social living of a modern society $[6, p$. 186].

Second basic form of efficiency is the benefit (B). "There is a difference between a useful result and costs of actions" [11, p. 19]. Nonetheless, according to another concept, "it is the difference between utilitarian result and the outlays required for its achievement that is, it is the utilitarian effect (E) minus outlays (C costs)" [13, p. 22-24].

$$
\mathrm{E}-\mathrm{C}=\mathrm{B}
$$

as the cost of action (outlays), we will obtain the Benefit, similarly to effectiveness, may be positive, neutral or negative. If we take $\mathrm{R}$ as an utilitarian result and $\mathrm{C}$ following situations [13, p. 24; 11, p. 24]:

$$
\begin{aligned}
& \mathrm{R}>\mathrm{C} \text { - beneficial action } \\
& \mathrm{R}=\mathrm{C} \text { - neutral action from the point of view of } \\
& \text { benefit } \\
& \mathrm{R}<\mathrm{C} \text { - unbeneficial action. }
\end{aligned}
$$

At the same time, both the effects and the outlays should not necessarily be viewed only in the financial dimension, but rather in a general one. One can 'scrape together' big amount of money, but his health or family relations may deteriorate. On the other hand action could be ineffective but turn up to be beneficial. Let us assume that somebody wanted to write his doctoral thesis. He went to the library and read books and, at the end, failed to write the thesis but met a beautiful librarian and married her eventually [13, p. 24].

There exist the following variants of relationship between effectiveness and benefit: [11, p.19-20]:

- effective but unbeneficial action,

- ineffective but beneficial action,

- effective and beneficial action - efficient action,

- ineffective and unbeneficial action.

Third basic form of efficiency is the economy. W. Kieżun defines it as "relationship between utilitarian effect (E) and costs (C) of action" and W. Kobyliński calls it the quotient of effect and outlays [11, p. 25; 13, p. 20]:

$$
\mathrm{E}_{\mathrm{c}}=\frac{\mathrm{E}}{\mathrm{C}}
$$

where:

$\mathrm{E}_{\mathrm{c}}$ - economy,

E - utilitarian effect,

$\mathrm{C}$ - costs.

The essence of economy is described by the relationship between effects and outlays needed for their achievement. If this is the case, then:

$\mathrm{E}_{\mathrm{c}}>1-$ action is economic;

$\mathrm{E}_{\mathrm{c}}=1-$ action is economically neutral;

$\mathrm{E}_{\mathrm{c}}<1-$ action is not economic.

A natural striving of every thinking human is increasing this ratio of economy, so that it is as big as possible and higher then 1 . This can be achieved in two ways:

- increasing the effect under constant costs

$$
\frac{E \uparrow}{C \rightarrow}
$$

or

- the same effect under decreased costs

$$
\frac{E \rightarrow}{C \uparrow}
$$

These are two different ways of increasing the economy ratio of our actions. When speaking about increased effect under constant costs, we refer to the type of economy that can be called productivity (3). On the other hand, if we decrease costs, we refer to the second form of economy, which can be called economizing (4) [13, p. 25-26].

Organizational efficiency may also be regarded from the point of view of profit maximization with the use of different means. Such maximization, if achieved with the use of economic and technical means, is connected with productivity. If its achievement is accompanied by other non-economic or political means, the increased efficiency does not contribute to increase of productivity. Increase of efficiency achieved with both mentioned types of means usually manifests itself as: storing energy, growth, survival and endurance of organization and as increase of organization's control over external environment [10, p. 264-265].

In Polish literature, an interesting attempt to build a multi-criterion model of organizational efficiency evaluation was made by M. Bielski and J. Olszewski. Namely, they distinguished seven dimensions of efficiency and defined for each of them appropriate criteria 
of efficiency and their measures or indicators [3, p. 120]. In the above mentioned theory, the following dimensions of organizational efficiency were distinguished:

- material, referring to realization of company's mission,

- economic, referring to relation between effects and outlays,

- system, describing "health" of the organization system and its ability to exist in a given surrounding,

- "political", referring to organization's relationship with its surrounding,

- political - without the inverted commas - referring to the organizational efficiency in preserving (or disturbing) the existing political and social order in a country,

- cultural - referring to the ability of an organization to preserve and/or change existing cultural values and norms in the social surrounding,

- behavioral - representing the interests of members of an organization [8, p. 87].

Material dimension refers to realization of the genotype function of the organization. It says how effective an organization is in fulfilling specific social needs and to what degree it achieves its external goals. Similarly to efficacy from the praxeology point of view, this dimension does not consider the cost of achieving goals. Therefore, this dimension has greater meaning in evaluation of efficiency of non-profit organizations, which fulfill social needs that are harder to quantify as outlays and effects. For example, a measurement of efficiency of school or university should be the level of education of its graduates and not the cost of their training. However, this dimension has also got meaning when efficiency of some economic entities is evaluated, especially in case of lack of some products or services in the market [3, p. 114].

Economic dimension (economic efficiency) encompasses criteria which in various ways present the relation between effects and outlays. If it is the relation between effects and outlays, then the criteria are: performance (people, equipment), productivity (fixed assets, property) or profitability. This corresponds with praxeological concept of economy. If there is a difference between effects and costs, it is measured by profit (reflecting praxeological benefit).

Economic efficiency is relatively easy to determine in economic entities, although even in this case exist effects and costs which are hard to present in terms of money (i.e.: intellectual, knowledge input of specialists). In non-profit organizations the economic dimension has often got smaller meaning than the material dimension; simultaneously, the economic measurability of outlays and - even more so - effects, is smaller. The measure of efficiency in these organizations is often the dynamics of outlays, i.e.: their decrease in comparison to the previous period while keeping the effects at the same level, expressed in material terms (i.e.: by the number of beds or patients in a hospital, students in a university, etc.) [3, p. 114-115].

System dimension (system efficiency) refers to "health" of the organization system and its ability to exist in a given surrounding. This dimension is especially underlined by the supporters of system approach to organizational efficiency. Without doubt, it is an important aspect of this efficiency. However, bringing the whole issue to this aspect only, brings about the sin of one-sidedness, similarly to the purposefulness approach. The evaluation criteria in case of this efficiency dimension are the long-term goals of an organization: survival and development, as well as adaptation to the changing environment.

It should be noted - says M. Bielski - that the goal of surviving cannot be graduated, as the organization either exists or not. Nonetheless, even in this dimension, the efficiency can be graduated, as a state of threat to the survival, i.e. threat of bankruptcy, may itself be an indicator of low organizational efficiency. Development and adaptation will reveal themselves in organization growth, investments, starting new businesses, expanding into new markets etc. [3, p. 115].

"Political" dimension ("political" efficiency) refers to organization's relationship with its environment. D. Katz and R. L. Kahn point out to the fact, that the ability to run a policy towards the environment by the organization is, next to efficiency, and important element of efficiency. With the same efficiency of transformation processes, organization efficiency may be different, depending on skillful placing of orders, cleverness in trade negotiations, right choice of place for investment etc. "In general, [...] it can be said that transactions with the environment have, to some extent, a political character..." [10, p. 252].

The result of "politics" in this sense is the exploitation of the environment, which is, obviously, only possible within limits in which it does not threaten the future of the organization (limits to "robber economy"). "Political" actions may just as well be directed towards in- 
side of the organization and aim at achieving the best possible (from the point of view of organization) conditions of people's participation, i.e.: work in extra hours, intensification of efforts, limitation of wage claims. Criteria of the "political" dimension can be bargain force of the organization against the environment, monopolistic position, bargain force in negotiations with employees and other stakeholders of the organization.

The inverted commas in this dimension refer to the organization politics towards other entities, sort of "small politics", as opposed to "big politics" [3, p. 115-118].

Political dimension (political efficiency) - without inverted commas - refers to company efficiency in preserving (or disturbing) the existing political and social order in a country. It is organizational efficiency from the point of view of not the organization itself, but the ruling class or political party. Although organization efficiency is only seldom officially evaluated with the use of this dimension, it is used commonly in real life. In countries ruled by communists, especially soon after overtaking the power, this dimension ousted out all the others, especially the economic one. Also, it influenced investment decisions which aimed at creating big economic entities and, at the same time, working class centers [3, p. 118].

Cultural dimension (cultural efficiency) refers to the ability of the organization to preserve values and norms, which enable the society to keep its cultural identity, as well as to contribute to the development of culture (in broader understanding: technical, organizational, sanitary, and not the strict sense) and to adapt to the changes in culture on global scale [3, p. 118].

Behavioral dimension (behavioral efficiency) encompasses such criteria as job satisfaction, increase of internal conflicts, employees' morale, etc. This dimension reflects the interests of members of an organization, and is used for evaluation from their point of view, but not only. Efficiency of an organization in this dimension may increase the efficiency in other dimensions, such as: material, economic, system. It might also be positively correlated with the political dimension - conflicts in workplaces, when they exceed certain degree of intensity, often turn into political conflicts (i.e.: conflicts in the Gdansk Shipyard in 1970 and 1980, strike of miners in Great Britain). On the other hand, this dimension could be totally inconsistent with the others, especially with the "political" and economic ones (high efficiency and high satisfaction do not always accompany each other) [3, p. 119].
In the Polish literature concerning organizational efficiency, purposefulness is also represented by L. Krzyżanowski [15]. What is doubtful, however, is the measurability of goals in an objective way. Goals are sometimes hard to grasp. According to D. Katz and R. L. Kahn, one of the key factors serving the purpose of organizational efficiency evaluation are the relations with the environment (transactions, bargain force, etc.). This argument is also not settled by the proposal of S. Kownacki. Therefore, at this point, it is interesting to present, above all, the scheme of efficiency dimensions of M. Bielski [3, p. 62]:

- end goals - means and their use (most similar to purposefulness approach),

- entry efficiency - transformation efficiency - exit efficiency (most similar to system approach),

- economic measurement of efficiency - behavioral measurement of efficiency (presenting the content of social sub-system of an organization),

- goal realization - maintaining the organizational integrity - adaptation,

- production - efficiency - morale - adaptation - development.

These proposals point to the complexity of the issue of organizational efficiency evaluation. On this background, it is clearly visible that praxeological evaluation criteria of aspects of organizational efficiency evaluation, useful as they are, do not completely exhaust the matter of synthetic efficiency evaluation. Other concepts of multi-criteria efficiency evaluation aim at measuring efficiency on the basis of goals, conditions to be met and standards. Subsequently, their authors define goals as "desired end result determined by management", and the conditions to be met are dependent on the type of organization. I.e. In a company this could be the quality of products, in school - quality of education, in hospital - number of successful surgeries, etc. Nonetheless, also this proposal appears to be incomplete [1, p. 106].

\section{Managerial efficiency}

While the problem of efficiency (especially economic) has been sufficiently elaborated upon theoretically in the literature, there is no such basis in the universal sense. Problem of efficiency as researched by the theory of organization and management is way more complex than in case of pure economy. It results from the fact that organization theory researches the efficiency 
of divergent goals, not only economic, but also those that can be attributed to economic entities and their constituent parts. Therefore, these can be even humanistic goals of functioning of organizations, such as: security, distinction, coherence, survival. In the theory of organization, concepts of adequate goals hierarchy and hierarchical organizational structure are used and the degree of inconsistence of goals realized by the organization and its specific parts is researched [1, p. 88-89].

Managerial efficiency measurement may be viewed from different angles: technical and economic, praxeological, administrative, bureaucrat, adaptive, humanistic, personality, organizational, ecological and ethical [7, p. 151].

Technical and economic aspect of efficiency. Identifying the concept of efficiency with the notion of productivity is typical for technicians and economists. H. Emerson, representative of the direction of scientific management, specialist from the field of organization and production management and author of the first concept of goal management, formulated twelve principles of efficiency (productivity), which deserve to draw the attention of modern managers and should be implemented in companies.

Creativity in an effective organization must be viewed as process and constant element of activity. Principles of efficiency presented by Emerson currently find full confirmation and are applied practically by those companies which base their activity on quality [2, p.193].

H. Emerson presents the 12 principles of efficiency as follows:

- clear goal and defined ideal (clearly defined goal),

- common sense,

- professional advice,

- discipline,

- fair, just behavior,

- flawless, immediate reporting,

- order in the course of action,

- standards and norms (standard ways of operation standard methods and operations),

- adjusted conditions

- standardized working methods,

- written instructions for standardized work (written regulations and instructions),

- prize for productivity (rewarding efficiency) [7, pp. 151-152].
Praxeological aspect of efficiency. "Efficiency is a feature of actions which bring some positively evaluated result, no matter if this result was intentional (efficacious action) or unintentional (efficient action). Efficiency, similarly to efficacy, may be upgradable or gradable. In the first case the action is either efficient or inefficient. In the second, the quantity and quality are considered and so the more efficient action is the one to bring bigger number of positive results or simply more valuable results: [7, pp. 154-156].

Administrative aspect of efficiency. Principles of rational administration of an industrial organization were formulated and published on the basis long-term research by H. Fayol. It consisted, above all, in increasing the efficiency of managers who ran the company. In 1916 principles of efficient company management and human resources management were published.

H. Fayol made it clear, that his principles did not have an absolute nor rigid character and that they should be adjusted to each and every situation (intelligently and within reason), in order to increase the efficiency of an industrial organization's management.

Below are the 14 principles of efficient administration according to H. Fayol:

- division of work,

- authority,

- discipline,

- unity of command,

- unity of Direction,

- subordination of individual interest,

- just remuneration,

- centralization,

- scalar chain (Line of Authority),

- order,

- treating employees well,

- stability of Tenure of Personnel,

- initiative,

- team spirit (Esprit de Corps).

Bureaucratic aspect of efficiency. Concept of bureaucracy was introduced by $M$. Weber as a name for an organization which was supposed to reflect the highest human rationality and efficiency.

Rationality meant adaptation of an institution to all goal-oriented actions with exclusion of everything that could directly or indirectly conflict with the marked out goals. 
The model of a rational, bureaucratic organization should have some specific, advisable attributes such as [7, p. 158-160]:

- purposefulness of action,

- precision of action,

- quickness,

- unambiguous character,

- activity continuity,

- discretion,

- subordination,

- minimization of conflicts,

- personal and material costs economy.

Basic principles of an efficient bureaucracy activity of M. Weber are:

- rules and procedures determine the scope of activity of organization and officials' competences,

- hierarchical structure and norms regulate the superiority-subordination relationships,

- qualifications and commitment are included in the employee work documentation,

- official is loyal to the office and not to his superior.

- official relationship is impersonal and functional with regard to tasks,

- rights and responsibilities of an official define his position in the office and in the society,

- status of an official is high due to his qualifications and permanent connection to the office [16].

Adaptive aspect of efficiency. A more modern type of efficient management of an organization which aims at improvement was proposed by R. Beckhard.

Forms of management of an organization which is open to changes look as follows:

- whole organization, its parts and units are goaloriented and plan the achievement of goals,

- forms are results of functions; given problem, task or project imposes the way of staff organization,

- decisions are made by people who are closest to the source of information, no matter their position in the official hierarchy,

- managers are equally rewarded or punished (so called stimuli) for: carrying out short-term tasks, training their subordinates and creating efficient teams,

- people are open, speak of facts and feelings known to them (communicate). Vertical and horizontal information flows are encouraged,

- "win or lose" behavior occurs rarely; conflicts are considered problems to be solved,
- if any difficulties occur, they are rather related to realization of tasks and projects than to interpersonal misunderstandings,

- organization and its individual parts realize themselves through interactions with the environment,

- given system of values is accepted by all the members,

- work of the whole organization and its individual parts resembles research, which consists in starting feedback mechanisms in a way that enables learning from one's own experience.

Humanistic aspect of efficiency. Model of an efficient organization was first presented from the humanistic point of view, among others, by D.J. Lawless, who made the assumption that there cannot be an efficient organization without efficient teams of people. Therefore, a model of efficient team is built.

Conditions for functioning of the efficient team of D.J. Lawless are as follows:

- atmosphere which supports informal behavior and provides feeling of relaxation,

- before approaching to the realization of tasks, discussion and agreement concerning means and methods are required,

- goals and tasks must be formulated in such a way that everybody can understand them and engage in their realization,

- the rule of listening to what other people have to say should be complied with. Each and every idea should be considered seriously and nobody should be afraid of being laughed at,

- causes of disagreement should be analyzed with the thought of finding a solution in mind, and not the thought of crashing the opposing party or removing the quarreling persons,

- most decisions should be taken under certain forms of understanding and agreement. Formal vote with use of the rule of simple majority of votes is not the best basis for an efficient team cooperation,

- criticism should be common, sincere criticism should not cause threats,

- during discussion of problems, which have to be resolved, showing emotion is allowed,

- each person's assignments should be understandable and accepted by this person,

- in order for the team to be able to realize the task, the issue should be "how to perform the task in the best way?" and not the fact who has the power or who has the control, 
- efficient team should always be aware of its behavior and undertaken actions [7, p. 161-162].

D. J. Lawless enumerates and describes dependent variables which are positively correlated with organizational efficiency. These variables are:

- productivity,

- morale,

- adaptation,

- flexibility,

- institutionalization,

- $\quad$ stability [7, p. 162-163].

Personality aspect of efficiency. Main assumption of the concept of efficient personality is that efficacy does not equal efficiency, because efficacy describes only the current level of task realization by given person, while efficiency describes the degree, to which given person exceeds his actual tasks. In the second case, therefore, "efficiency is the developmental efficacy" [7, p. 164; 22].

This difference in meanings is explained with the fact that the social environment values "efficacious behavior" more than "efficient behavior". It happens so because the first behavior is easy to evaluate and reward, while the second one is hard to evaluate in the short run, risky, uneconomic and threatens the realization of plans "for today". The drawback of "efficacious behavior" is, however, that it might be disturbed facing change, which, in consequence, leads to decrease of its efficacy [7, p. 164].

According to this author, only realization of a complete set of hierarchically organized tasks ensures strong and flexible developmental effectiveness, which is characteristic for an efficient person [7, p. 116].

Organizational aspect of efficiency. Managerial efficiency in teamwork organization may be achieved, among others, thanks to the use of six rules of B. K. Scanlan, which in practice are uncomplicated and inexpensive.

Principles of efficient teamwork organization of B. K. Scanlan are:

- define and maintain high requirements with regard to the results,

- inform people about their current position,

- introduce clear rules of communication,

- create atmosphere of encouragement and support,

- learn to delegate responsibility, rights and obligations,
- create a system for evaluating and directing [77, p. 167-171].

Ecological aspect of efficiency. The XX century was massively influenced by three inter-related factors: demographic explosion, industrialization and urbanization. Treated apart of each other as well as altogether, these factors cause threat of irrevocable changes in the natural environment of human being. These threats are magnified by extraordinary wastefulness with regard to use of resources, energy, produced goods, food, etc.

Proof of an increased ethical and ecological awareness may be the Code of Ethics in Business Activity published by the Polish Chamber of Commerce [7, p. 172177].

There is an opinion that "in order to stay alive and develop the civilization, human being inevitably has to interfere with other beings' lives and dwellings. To be rational and ethical rather than destructive, this integration has to follow such principles as:

- principle of self-defense,

- principle of proportionality,

- principle of lesser evil,

- principle of just division.

Compliance with the above mentioned principles instead of life and death struggle introduces the well known, rational and moral rule: "live and let others live" to human coexistence with the nature $[25$, p. 9699; 33, p. 61-61].

\section{Problems of efficiency and effectiveness}

\subsection{Increasing organizational efficiency}

If we assumed that activity of companies as well as their sub-systems, viewed as economic systems, should be effective, efficient and rational, then the managerial decisions should be preceded by economic calculation, which ought to constitute the basis for economic choices [2, p. 95].

Effectiveness answers the question if, as a result of activity, the set up goals were achieved. Efficiency, on the other hand, informs us about the costs that were incurred in order to achieve those goals and if these costs were exceeded by the obtained effects. Every company can be effective and efficient, effective and inefficient, efficient and ineffective and finally ineffective and inefficient. The last situation qualifies the company for 
bankruptcy and liquidation. A simplified example is presented in Table 2.

Table 2. Effectiveness and efficiency of company activity (source: [2, p. 96])

\begin{tabular}{|l|l|l|l|}
\hline \multirow{2}{*}{ high } & \multicolumn{2}{|c|}{$\begin{array}{c}\text { Degree of use of production } \\
\text { resources }\end{array}$} \\
\cline { 3 - 4 } $\begin{array}{l}\text { Degree } \\
\text { of goal re- } \\
\text { alization }\end{array}$ & $\begin{array}{l}|c| \\
\text { strong }\end{array}$ & \multicolumn{1}{|c|}{ weak } \\
\cline { 3 - 4 } & & $\begin{array}{l}\text { effectiveness } \\
\text { high } \\
\text { efficiency }\end{array}$ & $\begin{array}{l}\text { high } \\
\text { effectiveness } \\
\text { weak } \\
\text { efficiency }\end{array}$ \\
\cline { 2 - 4 } & low & $\begin{array}{l}\text { low } \\
\text { effectiveness } \\
\text { high } \\
\text { efficiency }\end{array}$ & $\begin{array}{l}\text { low } \\
\text { effectiveness } \\
\text { weak } \\
\text { efficiency }\end{array}$ \\
\hline
\end{tabular}

Indices of productivity and intensity. Indices of productivity of production factors are part of the efficiency ratios family. Productivity indices refer to production assets (assets productivity ratio), materials (material productivity ratios) and employees (labour productivity indices). The opposite of productivity is intensity of those factors with regard to the financial or material result, which is the assumed basis for calculations. Therefore - as pointed out by L. Białoń - such ratios as: capital intensity, material consumption, water absorption, energy consumption or knowledge intensity are used.

While the productivity ratios should increase in time, the smaller the intensity ratios, the better (maybe excluding knowledge intensity). Productivity indices describe the efficiency of production factors and intensivity indices describe the input-side of manufacturing processes $[2$, p. 96].

In order to diagnose the situation and improve organization results, the three efficiency levels approach is used. It may be used by the managerial cells to diagnose the situation before introducing specific solutions. Use of this approach should, at best, enable a given specialist to adjust the "remedy" to the situation. In the worst case scenario, it may occur that the proposal presented by a given department does not resolve the most urgent problems of the organization and, therefore, needs to be revised [27, p. 138-139].

\subsection{Organizational level}

At this level emphasis is placed on relations between the basic structural part of organization and the market, on which it operates. Factors which influence the organizational efficiency at this level are: strategy, general goals of the organization and methods of their measurement, organizational structure, method of use of resources [27, p. 138-139].

In order to conduct an efficient analysis of the social aspect of organization functioning, analysis of strategic plans of the organization is carried out - marked out goals, ways of designing and managing at the level of organization.

Organizational goals. Goals at the level of the organization as a whole result from the adopted action strategy. All the other efficiency levels and variables affecting efficiency result from organizational goals [27, p. 47].

Organization design. This efficiency variable is, above all, related to organizational structure. System approach suggests that structure analysis should contain not only the demarcation between individual organizational departments and reporting paths, but also how the work is carried out and if the present method of its realization has sense [27, p. 48].

Managing the organization. Organization might have properly formulated goals and appropriate organizational structure, which enable it to function efficiently. However, in order to operate efficiently and productively, it must be managed. The most important areas of management at the organizational level are:

- organizational goal management,

- efficiency management,

- resources management,

- point of contact management [27, p. 48-49].

The first step in efficiency management at the organizational level is to look at the current situation from the following points of perspective:

- client perspective,

- supplier perspective,

- employee perspective,

- shareholder perspective. 
First task of increasing the organizational efficiency is preparation of organizational mission. After preparing the strategy, activities connected with improving the organization have to be planned (as well as management methods). This consists in elaboration of super-system organizational map and determining, on its basis, the key issues for the organization.

These are potential chances for building strategic advantage of our company or reducing the advantage of competition. During realization of this stage it is also necessary to identify the processes, which, after the improvement, will have the biggest influence on the key issues for the organization.

Process level. This level refers to all the effects of organizational functioning, which result from the network of inter-department processes, such as i.e.: designing new products, supply process, production process, sales process, distribution, invoicing and debt collection [27, p. 43].

Most basic results of the organization result from such inter-functional processes as: realization of order, invoicing, supplying, designing new products, client service or preparing sales forecasts. Three needs of efficiency at the process level are: goals, design and management.

Process goals. Because work is a result of processes, for each process we should establish goals. Process goals, which are connected with the external client (i.e. sales, providing services, invoicing) should result from organizational goals and consumers' expectations and requirements. Goals for inner-organizational processes (such as: planning, budgeting, personnel recruitment) should be formulated on the basis of inner-clients' needs [27, p. 50].

Process design. Having formulated process goals, we should make sure if the way the processes were designed enables efficient realization of our goals. This process should be logical and have the simplest possible course which enables the achievement of goals [20, p. 51]

Process management. A process, even if it has the most logical structure, will be inefficient, if it will not be managed properly. Process management encompasses the same components as managing the organization [27, p. 51-52].

Having identified the key organizational issues and process, we can initiate the project of process im- provement. Next, we should realize in turn the stages of the earlier mentioned procedure. During the first stage we should define: goals, roles and operational framework of the project. Second stage is devoted to description and analysis of the current state of the process and, afterwards, designing new process in accordance with goals defined earlier. Finally, the measurement system is established.

The above mentioned tasks are realized by the management and employees who are indirectly involved in the process realization. Detailed action and implementation plan of the improved process, which encompasses all three levels of efficiency evaluation, appears during realization of the third stage [27, p. 261].

Nine variables which influence organizational efficiency. Three efficiency levels are the first dimension of the G. A. Runner and A. P. Brache's concept. The second one consists of three factors, so called efficiency needs, which influence the results on every level and, therefore, also the organizational results. Efficiency needs result from:

- organizational, process and workstation goals they must be defined with the use of standards reflecting clients' expectations concerning: quality, quantity, time of delivery, time of realization and cost of product or service,

- design method - organizational structure, process design and workstations require some vital elements configured in the way, which enables efficient goal realization,

- management method - each of the three levels of efficiency requires an appropriate method of management, which enables goal realization [27, p. 46].

G.A. Rummler, A.P. Brache state that all the time we tend to try to search for new methods of using the tools of three efficiency levels for three potential groups of users: highest level managers, managers and consultants. These might be used as:

- tools for diagnosing and improving those organizations which function inefficiently,

- method of constant improvement of systems which run efficiently,

- approach which enables formulation of new organizational strategy,

- procedure allowing us to design new organization from the beginning. 
Table 3. Nine variables influencing organizational efficiency (source: [27, p. 46])

\begin{tabular}{|c|l|l|l|l|}
\hline \multirow{2}{*}{} & \multicolumn{4}{|c|}{ EFFICIENCY NEEDS } \\
\cline { 2 - 5 } & & \multicolumn{1}{|c|}{ goals } & design method & management method \\
\cline { 2 - 5 } & organizational & organizational goals & $\begin{array}{l}\text { organization } \\
\text { design }\end{array}$ & $\begin{array}{l}\text { organization } \\
\text { management }\end{array}$ \\
\cline { 2 - 5 } & process level & process goals & process design & process management \\
\cline { 2 - 5 } & workstation level & workstation goals & $\begin{array}{l}\text { workstation } \\
\text { design }\end{array}$ & $\begin{array}{l}\text { workstation } \\
\text { management }\end{array}$ \\
\cline { 2 - 5 } & & &
\end{tabular}

As a result of the research carried out so far, it can be said that the described issues do not only serve the purpose of resolving specific, current problems. Implementation of the mentioned activities may influence a change in the organizational culture. Within the framework of influencing the organizational culture, it is possible to affect:

- recognition of clients' needs as a point of reference for all organizational activities,

- introduction of responsibility for taken actions on the basis of results of efficiency evaluation system,

- minimization of conflicts between departments,

- introduction of a participation management style, that is, such management style, in which the voice of all the people interested in resolving particular problems is taken into account,

- creation of such working conditions which are favorable to efficiency and job satisfaction improvement [27, p. 263-264].

\section{Summary}

Company which wants to maintain its position in the market must: be productive, use the material and human resources efficiently and positively influence the relation between effects and outlays [2, p. 197].

When approaching to evaluate company efficiency, the following conditions must be taken into account: company and its individual parts are goal-oriented; forms are results of functions, particular problem influences the way people should be organized; system of stimuli functions in such a way that managers of different levels are rewarded and punished to the same extent; employee training and creation of task-oriented teams take place; there is an effective vertical and horizontal communication; conflicts between people are treated as problems to be solved; organization is an open system, which has relationships with the environment; there is a system of values supported by the managers; functioning of the whole organization serves the purpose of starting processes which enable learning [7, p. 37-64].

The process of achieving efficiency must engage all the factors, which may influence the success of the organization. It is, therefore, necessary to determine the basic and supporting goals as well as strategies of their realization, to care for the quality of inner activities within the organization and, for the same purpose, full readiness for cooperation and flexibility towards changes. Company, which is not able to subject itself to the process of changes, is doomed to leave the market. Therefore, there must not be a single day, when there is no change for the better in the organization [2, p. 192].

Management efficiency depends on the used rules and aspects of good management. It is a common belief, that quality management (TQM) influences the economic efficiency, which further impacts the organizational efficiency. Total quality management leads to improvement of organization, personnel, information flow and communication between employees [2, p. 96].

An important tool for improvement of efficiency is the effective leadership. It starts in the moment when vision is formulated and expands over the strategy, which is supposed to lead to market success. Efficient leadership combined with TQM provides the result of appropriate goods achieved from the first time [21, p. 12-72]. 
Other important tools for improvement of efficiency are: reengineering, motivation systems and kaizen, which is the philosophy of introducing small, simple changes with the use of small steps approach. Simultaneously, it is important to underline that the initiative, which leads to changes, comes from the place where the product is being manufactured and the value is being added. Kaizen is a process which consists in adopting the mentality of constant improvement [2, p. 192].

Efficiency is a measure of results. It consists in asking a simple question: Was the task accomplished? Rewarding people within the organization requires, therefore, the existence of an agreed upon criterion of evaluation of their efficiency.

The fact, whether such criterion successfully describes the efficiency has no meaning; if we grant a prize on the basis of effective execution of tasks, we treat efficiency as its measure. In many works efficiency is treated as the only criterion. However, together with tasks becoming less normalized and routine, it becomes more difficult to measure efficiency. Consequently, defining efficiency becomes more and more complex matter [26, p. 394].

Nonetheless the managers in corporations as well as those who directly monitor separate economic entities rely more and more on linking the rewards (especially remuneration) with efficiency. Such different companies as i.e.: American Broadcasting, Security Pacific National Bank, Sears, Roebuck and Dow Chemical all measure the economic efficiency of their economic entities, compare results with those of their competition and grant rewards accordingly [26, p. 394].

The basic condition of efficient management becomes the understanding and respect for human being in an organization and the awareness that "no organization can exist, if its members will not accept the tasks which are expected from them and will not be motivated to execute them" [10, p. 199-130].

It is similar in case of companies, which will achieve success in the future. It will be those of them which receive the most from their people (with regard to creative use of equipment - the same in all the companies). Therefore, from the point of view of increase in efficiency, very important role is played by: enriching work, which is a motivation strategy that underlines motivating function of the employee's own work.

Employees are responsible for successful realization of tasks. Usually, at this point the features, which influ- ence individual motivation and activity, are pointed out:

- variety of skills,

- setting the goal,

- meaning of the task,

- autonomy,

- return effect in the form of quantity of direct and clear information, which is received by the employee $[20$, p. 458,463$]$.

\section{References}

[1] Bednarski A., - Zarys teorii organizacji i zarzadzania. TNOIK, Toruń 1998.

[2] Białoń L. - Ekonomika przedsiębiorstwa. Oficyna Wyd. Politechniki Warszawskiej, Warszawa 1996.

[3] Bielski M. - Organizacje. Istota, struktury, procesy. Wyd. Uniwersytetu Łódzkiego, Łódź 1996.

[4] Bobak A. - Produktywność standardowa i strukturalna [in] Encyklopedia zarządzania,

http://mfiles.ae.krakow.pl/, 06-2009.

[5] Borowiecki R. (red.) - Efektywność przedsięwzięć rozwojowych. Metody, analiza, przykłady. AE, Kraków 1995.

[6] Drucker P.F. - Menedżer skuteczny. Biblioteka Nowoczesności, AE Kraków, „Czytelnik”, Kraków 1994.

[7] Holstein-Beck M. - Menedżer poszukiwany. CIM, Warszawa 2001.

[8] Kaczmarek B., Sikorski Cz. - Podstawy zarzadzania. Zachowania organizacyjne. Wyd. Absolwent, Łódź 1996.

[9] Kamiński T. - Ocena ekonomicznej efektywności dylematy teorii i praktyki [in] Ocena efektywności funkcjonowania organizacji gospodarczych (ed. Bombera Z., Telep J.). Wyższa Szkoła Ekonomiczna w Warszawie, Warszawa 2004.

[10] Katz D., Kahn R.L. - Społeczna psychologia organizacji. PWN, Warszawa 1979.

[11] Kieżun W. - Sprawne zarzqdzanie organizacja. SGH, Warszawa 1997.

[12] Kister A. - Zarzqdzanie kosztami jakości. Oficyna Ekonomiczna, Kraków 2005.

[13] Kobyliński W. - Podstawy organizacji i kierowania w oświacie. SOP, Warszawa 1996.

[14] Koch R. - Stownik zarzqdzania i finansów. Wyd. Profesjonalnej Szkoły Biznesu, Kraków 1997.

[15] Krzyżanowski L. - Podstawy organizacji i zarzqdzania. PWN, Warszawa 1992.

[16] Kuebler-Ross E. - Koło życia. Świat książki, Warszawa 2000.

[17] Lis St. (ed.) - Vademecum produktywności. Agencja Wydawnicza „Placet”, Warszawa 1999. 
[18] Muhlemann A.P., Oakland J.S., Lockyer K.G. Zarzadzanie, produkcja $i$ ustugi. PWN, Warszawa 1995.

[19] Narski Z. - Praktyka zarzqdzania przedsiębiorstwem. Wyd. A. Marszałek, Toruń 1999.

[20] Nickels W.G. - Zrozumieć biznes. Wyd. Bellona, Warszawa 1995.

[21] Oakland J.S. - Total Quality Management. Butterworth-Heinemann, Oxford 1992.

[22] Obuchowski K. - Badania osobowości efektywnej. [in] Efektywność a osobowość. Ossolineum, Wrocław 1982.

[23] Pawłowski M., Piątkowski Z., Wójcik-Kośla D. Logistyka w przedsiębiorstwie, część II. Logistyka jako funkcja sprawności organizacyjnej przedsiębiorstwa oraz zastosowanie logistyki w praktyce. [in] Postępy Techniki Przetwórstwa Spożywczego, No. 2, 2005.

[24] Penc J. - Leksykon Biznesu. Agencja Wydawnicza „Placet”, Warszawa 1998.

[25] Piątek Z. - Etyka środowiskowa. Nowe spojrzenie na miejsce czlowieka $w$ przyrodzie, Wyd. Uniwersytetu Jagiellońskiego, Kraków 1998.

[26] Robbins S.P. - Zachowania $w$ organizacji. PWE, Warszawa 1998.
[27] Rummler G.A., Brache A.P. - Podnoszenie efektywności organizacji. PWE, Warszawa 2000.

[28] Skrzypek E. - Jakość i efektywność. Wyd. UMCS, Lublin 2000.

[29] Ŝmid W. - Leksykon menedżera. Wyd. Profesjonalnej Szkoły Biznesu, Kraków 2000.

[30] Sowa K. (ed.) - Gospodarka nieformalna. Uwarunkowania lokalne i systemowe. TNOiK, Rzeszów 1990.

[31] Szpaderski A. - Postulat prakseologii jako teorii podstawowej dla nauk organizacji $i$ zarzadzania. Organizacja i Kierowanie nr 2, 2006.

[32] Sztucki T. - Encyklopedia marketingu. Agencja Wydawnicza Placet, Warszawa 1998.

[33] Waloszczyk K. - Ku ekorozwojowi [in] Zrównoważony rozwój (ed. Bogumił A., Greniewski M. J., Greniewski P., Krzyżanowski L.J., Rok B., Waloszczyk K). Oficyna Wyd. WSM SIG, Warszawa 2002.

[34] Żebrowski W., Pawłowski M., Piątkowski Z. Nowoczesne systemy zarzadzania produkcja, część II Sterowanie operacyjne [in] Postępy Techniki Przetwórstwa Spożywczego, No. 2, 2006. 